\title{
Mekong River flow and hydrological extremes under climate change
}

\author{
Long Phi Hoang ${ }^{1}$, Hannu Lauri ${ }^{2}$, Matti Kummu ${ }^{3}$, Jorma Koponen ${ }^{2}$, Michelle T. H. van Vliet ${ }^{1}$, Iwan Supit ${ }^{1}$, \\ Rik Leemans $^{4}$, Pavel Kabat ${ }^{1,5}$, and Fulco Ludwig ${ }^{1}$ \\ ${ }^{1}$ Water Systems and Global Change Group, Wageningen University, P.O. Box 47, 6700 AA Wageningen, the Netherlands \\ ${ }^{2}$ EIA Finland Ltd., Sinimäentie 10B, 02630 Espoo, Finland \\ ${ }^{3}$ Water \& Development Research Group, Aalto University, P.O. Box 15200, Aalto, Finland \\ ${ }^{4}$ Environmental Systems Analysis group, Wageningen University, P.O. Box 47, 6700 AA Wageningen, the Netherlands \\ ${ }^{5}$ International Institute for Applied System Analysis, Schlossplatz 1, 2361 Laxenburg, Austria
}

Correspondence to: Long Phi Hoang (long.hoang@wur.nl; long.hp2002@gmail.com)

Received: 16 October 2015 - Published in Hydrol. Earth Syst. Sci. Discuss.: 10 November 2015

Revised: 10 June 2016 - Accepted: 29 June 2016 - Published: 29 July 2016

\begin{abstract}
Climate change poses critical threats to waterrelated safety and sustainability in the Mekong River basin. Hydrological impact signals from earlier Coupled Model Intercomparison Project phase 3 (CMIP3)-based assessments, however, are highly uncertain and largely ignore hydrological extremes. This paper provides one of the first hydrological impact assessments using the CMIP5 climate projections. Furthermore, we model and analyse changes in river flow regimes and hydrological extremes (i.e. high-flow and low-flow conditions). In general, the Mekong's hydrological cycle intensifies under future climate change. The scenario's ensemble mean shows increases in both seasonal and annual river discharges (annual change between +5 and $+16 \%$, depending on location). Despite the overall increasing trend, the individual scenarios show differences in the magnitude of discharge changes and, to a lesser extent, contrasting directional changes. The scenario's ensemble, however, shows reduced uncertainties in climate projection and hydrological impacts compared to earlier CMIP3-based assessments. We further found that extremely high-flow events increase in both magnitude and frequency. Extremely low flows, on the other hand, are projected to occur less often under climate change. Higher low flows can help reducing dry season water shortage and controlling salinization in the downstream Mekong Delta. However, higher and more frequent peak discharges will exacerbate flood risks in the basin. Climatechange-induced hydrological changes will have important implications for safety, economic development, and ecosystem dynamics and thus require special attention in climate change adaptation and water management.
\end{abstract}

\section{Introduction}

The Mekong River basin is one of the most important transboundary rivers in Southeast Asia. Starting from the Tibetan Plateau, the $4800 \mathrm{~km}$ long river flows across six different countries, namely China, Myanmar, Laos PDR, Thailand, Cambodia, and finally Vietnam before draining into the East Sea (also known as South China Sea). The economies and societies along the Mekong are strongly linked to its abundant water resources (Mekong River Commission - MRC, 2010). The most important water-dependent economic sectors include agriculture, energy (i.e. hydropower production), and fishery (Västilä et al., 2010; MRC, 2011a). Currently, the Mekong basin is home to about 70 million people and this population is expected to increase to 100 million by 2050 (Varis et al., 2012). Economic development has been accelerating rapidly over the last decades together with substantial increases in water resources use (Jacobs, 2002; Lebel et al., 2005; Piman et al., 2013). Given high dependencies on water in the basin, the issues of securing water safety and long-term sustainability are especially important for water resources management.

Socio-economic developments in the Mekong River basin, however, are facing critical challenges relating to water resources, including hydrological changes caused by climate change (Keskinen et al., 2010; MRC, 2010; Västilä et al., 2010). Existing studies (e.g. Eastham et al., 2008; Hoanh et al., 2010; Västilä et al., 2010) suggest that climate change will alter the current hydrological regime and thus posing challenges for ecosystems and socio-economic devel- 
opments. For instance, Västilä et al. (2010) and Hoanh et al. (2010) modelled the Mekong's flow regimes under several climate change scenarios and suggested a likely intensification of the hydrological cycle, resulting in increases in annual and seasonal river discharges. Consequently, they also suggest increasing flood risks during the wet season in the Cambodian and Vietnamese floodplain due to increasing river flow. Other studies (e.g. Lauri et al., 2012; Kingston et al., 2011) also suggest possible discharge reduction in the dry season under some individual climate change scenarios.

Although many studies about climate change impacts on the Mekong's hydrology exist, two major challenges in understanding hydrological responses to climate change remain. First, existing hydrological impact assessments prove highly uncertain. In particular, impact signals differ markedly in the magnitudes and even directions of changes across the individual global circulation models (GCMs) and climate change scenarios. Kingston et al. (2011) quantified uncertainties related to the choice of GCMs and climate scenarios in projecting monthly discharge changes and show a large range between -16 and $+55 \%$. They also noted that hydrological changes under different GCMs and scenarios differ remarkably in magnitude and even in contrasting directions. Another study by Lauri et al. (2012) also reported a wide range of discharge change between -11 and $+15 \%$ during the rainy season and between -10 and $+13 \%$ during the dry season. Both studies noted the uncertainty in hydrological impact signals, which is mainly associated with uncertainties in the climate change projection, especially precipitation changes. Given these uncertainties, they all also stress the importance of using multiple GCMs and several scenarios (i.e. an ensemble approach) rather than relying on a single model or climate change projection. Compared to uncertainties in the future climate, uncertainties relating to hydrological models' schematization and parameterization seem less important for the Mekong basin. Regarding hydrological models' skill, many studies including Hoanh et al. (2010), Västilä et al. (2010), Kingston et al. (2011), and Lauri et al. (2012) reported sufficient performance in capturing the dynamics of the Mekong's hydrology. Several previous studies also reported lower modelling skill in the upstream stations (e.g. Chiang Saen) compared to the downstream stations (Kingston et al., 2011; Lauri et al., 2012; Wang et al., 2016).

Notably, all earlier studies are based on the SRES emission scenarios (Nakicenovic et al., 2000), which were used in the Coupled Model Intercomparison Project phase 3 (CMIP3). These scenarios, which only include non-intervention scenarios, have recently been replaced by the Representative Concentration Pathways (RCPs) scenarios (Van Vuuren et al., 2011; Stocker et al., 2013), resulting in a broader range of climate change. These most recent climate change scenarios (i.e. the CMIP5) are not yet routinely used to assess the hydrological impacts in the Mekong basin. The CMIP5 scenarios also exhibit important improvements, both in terms of the GCMs' technical development (Taylor et al., 2011; Knutti and Sedláček, 2013) and the efficiency to reproduce the historic climate conditions (Hasson et al., 2016). These important improvements and updates are highly relevant and require one to update the hydrological projections for the Mekong. In this study, we will do this update and reflect whether the CMIP3 uncertainties relating to the hydrological signal will be reduced as well.

Second, although hydrological extremes under future climatic change are very relevant for water management and climate change adaptation (Piman et al., 2013; Cosslett and Cosslett, 2014), very few insights have been gained on this topic so far in the Mekong. Previous studies typically analysed hydrological changes at monthly and seasonal timescales and few studies focused on changes in frequency and severity of extreme events (i.e. climate-change-induced floods and droughts). This knowledge gap also relates to the fact that uncertainties, especially those relating to future monsoon and precipitation changes, prevail in the CMIP3 climate change projections. Given high level of policy relevance and important improvements in CMIP5 climate change projections, future changes in extreme high and low river flows should be comprehensively assessed and made available to decision makers.

In this paper, we aim to address these knowledge gaps in understanding the Mekong's hydrology under climate change. A distributed hydrological model was set up and calibrated for the whole Mekong River (Sects. 3.1 and 4.1). We selected a set of 10 climate change experiments for five GCMs and two RCPs from the CMIP5 and performed a downscaling and bias correction on the climate model output (Sect. 3.2). Future changes in precipitation and temperature (Sect. 4.2) and subsequently the Mekong's annual and monthly discharge changes were quantified (Sect. 4.3). In addition, we quantified changes in hydrological extremes, focusing on both extreme low and high flows (Sect. 4.4). We will also reflect on the robustness of the hydrological signals and show improvements in uncertainty compared to other CMIP3-based studies (Sect. 5.1).

\section{The Mekong River basin}

The Mekong (Fig. 1) is an average-sized river basin compared to other major rivers of the world. Its total drainage area is about $795000 \mathrm{~km}^{2}$, distributed unevenly across six Southeast Asian countries (MRC, 2005). The river's annual discharge volume of $475 \mathrm{~km}^{3}$, is considerably higher than similarly sized river basins. Despite its moderate area, the Mekong ranks tenth in terms of annual discharge volume (Dai and Trenberth, 2002). This implies that the basin receives higher precipitation amount per unit area, owing to its dominant tropical monsoon climate (Adamson et al., 2009; Renaud et al., 2012). Elevation in the basin ranges between 


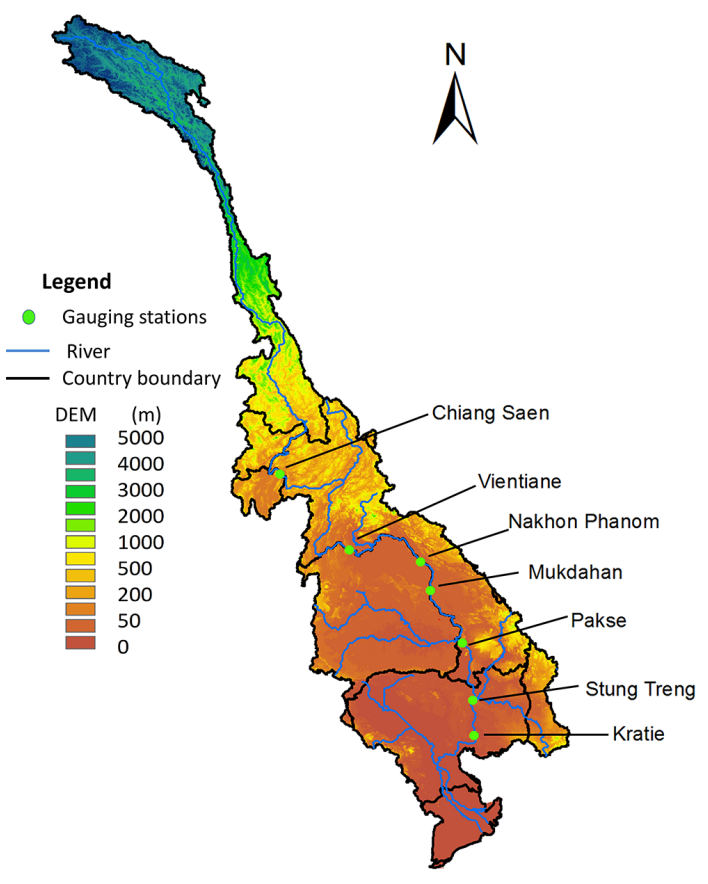

Figure 1. The Mekong River basin's elevation map and locations of mainstream gauging stations.

above $5000 \mathrm{~m}$ in the Tibetan Plateau to only a few metres above sea level in the downstream river delta.

The Mekong's hydrological regime is largely driven by monsoonal activities, most importantly the south-west monsoon and to a lesser extent the north-east monsoon (CostaCabral et al., 2008; MRC, 2009; Delgado et al., 2012). The south-west monsoon is dominant from May to September, whereas the north-east monsoon is active from November to February. These monsoonal activities characterize the basin's hydrology into two hydrological seasons with distinctive flow characteristics. A substantially larger proportion of the annual flow is generated during the wet seasons (JuneNovember). Depending on location, the wet season flow accounts for between 75 and $85 \%$ of the total annual flow (calculated from MRC, 2005). Seasonal variation in river flow, especially the flood pulse occurring in the downstream delta (i.e. the Tonle Sap Lake in Cambodia and the Vietnamese Mekong delta), supports a highly productive aquatic ecosystem and one of the world's major rice production areas (Lamberts and Koponen, 2008; Arias et al., 2012).

Hydrological changes, including changes in extreme high and low flows, increase safety risks and undermine economic productivity in the basin, especially in the low-lying river delta (Eastham et al., 2008; Arias et al., 2014). Extreme floods caused by intensive and widespread precipitation events result in vast inundation thereby damaging crops, infrastructure, and, in very extreme cases (e.g. flood events in 2000 and 2011), disrupting how the whole downstream delta functions. The catastrophic flood in 2000 with an esti- mated total economic loss of over USD 200 million (Cosslett and Cosslett, 2014) illustrates the severe flood damage that can occur in this area. Extreme low flows also affect agriculture production, which largely depends on surface water irrigation in many parts of the basin. Lack of upstream inflow during the dry season also exacerbates the risk of salt water intrusion, affecting the downstream delta's ecosystems, domestic water supply, and agricultural production (Smajgl et al., 2015).

\section{Methodology}

\subsection{Hydrological model}

VMod (Lauri et al., 2006) is a distributed hydrological model using a square grid representation of river basins. This grid uses multiple raster layers containing data for flow direction, river network, soil, and land use. The simulation process starts with interpolating climate input for each grid cell from climate input data. VMod requires minimally four daily climate forcing variables (i.e. maximum, minimum, and average air temperatures, and precipitation). Climate forcing data are calculated for each grid cell using an inverse distanceweighted interpolation. Potential evapotranspiration (PET) is calculated using the Hargraeves-Samani method (Hargraeves and Samani, 1982), where PET is calculated using daily maximum and minimum temperatures, latitude, and calendar day of the year. The soil is simulated as two distinctive layers and soil surface processes are simulated following Dingman (1994). After calculating the water balance, runoff is routed from cell to cell and finally into the river network. A detailed description of the VMod model's algorithms and equations is available in the model's manual (Lauri et al., 2006).

In this study, we used the modelling set-up for the Mekong River basin from Lauri et al. (2012). This Mekong modelling set-up was prepared from several soil, land use, and elevation data sets, allowing for daily hydrological simulation at $5 \mathrm{~km} \times 5 \mathrm{~km}$ spatial resolution. Soil data were prepared from the FAO soil map of the world (FAO, 2003). Soil data were prepared by first reclassifying the original data into eight classes and then aggregated to a $5 \mathrm{~km} \times 5 \mathrm{~km}$ grid. Land use data were prepared by reclassifying the original Global Land Cover 2000 data (GLC2000, 2003) into nine classes and then aggregated to the model's grid. The GLC2000 provides land cover data that are most suitable to our calibration and validation time period (i.e. 1981-2001). The flow direction data were prepared from the SRTM90m elevations (Jarvis et al., 2008). The elevation data along the main river's branches were adjusted to force these branches into the proper flow direction. More detailed information on the model set-up and its parameterization for the Mekong basin is available in Lauri et al. (2012). 
We calibrated and validated the hydrological model against observed daily river discharges at seven gauging stations: Chiang Saen, Vientiane, Nakhon Phanom, Mukdahan, Pakse, Stung Treng, and Kratie (Fig. 1). Observed discharge data were obtained from the Mekong River Commission's hydrological database (MRC, 2011b). Calibration and validation periods are 1981-1991 and 1991-2001, respectively. The hydrological model's performance was assessed using discharge plots and model performance indices. In particular, the daily river discharges plots and the flow duration curves (Vogel and Fennessey, 1995) were used to visually check the goodness of fit between observed and simulated data. Furthermore, the Nash-Sutcliffe efficiency (NSE; Nash and Sutcliffe, 1970) and relative biases indices were used to quantify the model's performance during calibration and validation. The model's over- and underestimation of total annual river discharge, high-flow, and low-flow indices (i.e. $Q_{5}$ and $Q_{95}$, respectively) were assessed by calculating the relative biases. These $Q_{5}$ (high flow) and $Q_{95}$ (low flow) are commonly used indices in hydrological analyses, defined as the values that exceed the discharge time series data by 5 and $95 \%$ of the time, respectively. The biases are calculated as simulated values divided by observed values under the same time period of interest.

We started the model calibration by using the initial parameterization from Lauri et al. (2012). Simulation performance was further improved by manually adjusting several model's parameters. In particular, discharge amount and timing at key stations were calibrated to better match with observed data by changing the two soil layers' depth and their water storage capacities. Vertical and horizontal infiltration rates were also adjusted to further improve simulations of high flows and low flows. Lastly, snowmelt rate and temperature thresholds for snow precipitation and snowmelt were adjusted to improve model performance at the upper catchment above Chiang Saen (northern Thailand). All parameter values were adjusted within the physically realistic range described in Lauri et al. (2006) and Sarkkula et al. (2010).

\subsection{Climate data}

We prepared climate data for the historic period (1971-2000) and the future period (2036-2065) using various data sets. Historic temperature was prepared from the WATCH forcing data (Weedon et al., 2011), which is a global historic climate data set for the 1958-2001 period, produced from the 40-year ECMWF Re-Analysis (Uppala et al., 2005) and biascorrected using the CRU-TS2.1 observed data (Mitchell and Jones, 2005). This data set is widely used in various global and regional studies (e.g. van Vliet et al., 2013; Leng et al., 2015; Veldkamp et al., 2015). Precipitation data were extracted from the APHRODITE data set (Yatagai et al., 2012), which is an observation-based precipitation data set, developed from a high-density network of rain gauges over Asia. This data set has been evaluated as one of the best gridded precipitation data sets for hydrological modelling purposes in the Mekong basin (Lauri et al., 2014). We further discuss potential implications of using the combined WATCHAPHRODITE data in Sect. 5.3.

We used the most recent CMIP5 climate projection to develop climate change scenarios. The scenarios were developed for the 2036-2065 period, i.e. mid-21st Century, which is a relevant time frame for long-term water resources planning and adaptation (MRC, 2011a). Since the regional climate model data of the Coordinated Regional Climate Downscaling Experiment (CORDEX; Giorgi and Gutowski, 2015) so far only covers one GCM for the Mekong region, we decided to use GCM projections as basis for this climate impact assessment. We therefore downscaled the GCM projections ourselves. Given the relatively large number of GCMs under CMIP5, we first did a model selection by reviewing literature on GCM performance. We selected those GCMs that better reproduce historic tropical temperature and precipitation conditions, implying their suitability to be used in the Mekong region. For historic temperature simulations, Huang et al. (2014) assessed the CMIP5 models efficiency for the Mekong basin and suggested BCC-CSM1-1, CSIROMK3-6-0, HadGEM2-ES, and MIROC-ESM-CHEM as the better-performing models. Hasson et al. (2016) evaluated the GCM's performance in simulating seasonal precipitation focusing on monsoonal activities for three major river basins in South and Southeast Asia, including the Mekong. They concluded that the MPI models, MIROC5 and CSIRO-Mk36-0, CCSM4, CESM1-CAM5, GFDL-ESM2G, IPSL-CMAMR, MIROC-ESM, and MIROC-ESM-CHEM perform better than other GCMs in the assessment. Furthermore, we also consulted the model evaluation of Sillmann et al. (2013) to represent climate extremes. They indicated that ACCESS1.0, CCSM4, MPI models, and HadGEM2-ES are amongst the better-performing models. Based on these GCM evaluations, we selected five GCMs for this study (Table 1). For each GCM, we extracted climate data for two different RCPs, namely RCP4.5 and RCP8.5. The RCP4.5 is a medium to low scenario assuming a stabilization of radiative forcing to $4.5 \mathrm{~W} \mathrm{~m}^{-2}$ by 2100 (Thomson et al., 2011). The RCP8.5 is a high radiative-forcing scenario assuming a rising radiative forcing leading to $8.5 \mathrm{~W} \mathrm{~m}^{-2}$ by 2100 (Riahi et al., 2011). By selecting a mid-range and a high-end scenario, we expect to capture a reasonable range in climatic and hydrological projections for the Mekong basin. Given our focus on hydrological extremes under climate change, we did not consider $\mathrm{RCP} 2.6$, which is the lowest radiative-forcing scenario.

Since the GCMs' spatial resolution is generally too coarse for a basin-scale study, we re-gridded the climate data to a $0.5^{\circ} \times 0.5^{\circ}$ grid using bilinear interpolation. Subsequently, the data are subjected to a statistical bias correction, using the method developed by Piani et al. (2010) to correct biases in the GCM simulations. This bias-correction is done by developing transfer functions, which match the GCM historic (1959-2000) data's monthly statistics to an independent, ob- 
Table 1. Selected CMIP5 GCMs for climatic and hydrological change assessment.

\begin{tabular}{llll}
\hline GCM name & Acronyms & Institution & $\begin{array}{l}\text { Resolution } \\
(\text { long } \times \text { lat })\end{array}$ \\
\hline ACCESS1-0 & ACCESS & $\begin{array}{l}\text { CSIRO-BOM - Commonwealth } \\
\text { Scientific and Industrial Research } \\
\text { Organisation, Australia and Bureau of } \\
\text { Meteorology, Australia }\end{array}$ & $1.875^{\circ} \times 1.25^{\circ}$ \\
\hline CCSM4 & CCSM & $\begin{array}{l}\text { NCAR - National Center for } \\
\text { Atmospheric Research }\end{array}$ & $1.25^{\circ} \times 0.94^{\circ}$ \\
\hline CSIRO- & CSIRO & $\begin{array}{l}\text { CSIRO-QCCCE - Commonwealth } \\
\text { Mk3.6.0 }\end{array}$ & $\begin{array}{l}\text { Scientific and Industrial Research } \\
\text { Organisation in collaboration with the } \\
\text { Queensland Climate Change Centre } \\
\text { of Excellence }\end{array}$ \\
\hline HadGEM2-ES & HadGEM & $\begin{array}{l}\text { MOHC - Met Office Hadley Centre } \\
\text { and Instituto Nacional de Pesquisas }\end{array}$ & $1.875^{\circ} \times 1.875^{\circ}$ \\
& & Espaciais & \\
\hline MPI-ESM-LR & MPI & $\begin{array}{l}\text { MPI-M Max Planck Institute for } \\
\text { Meteorology }\end{array}$ & $1.875^{\circ} \times 1.875^{\circ}$ \\
\hline & & &
\end{tabular}

served climatology. We used the WATCH forcing data and APHRODITE as independent data sets. The developed transfer functions were then applied on the future climate data to correct the biases in the GCM's future climate projection. Detailed information on the bias-correction method is available in Piani et al. (2010).

\subsection{Analysing hydrological changes}

We employed several techniques to analyse different aspects of hydrological changes. First, annual and monthly discharge statistics were calculated to understand changes in the river's flow regime. Second, we calculated the $Q_{5}$ and $Q_{95}$ to analyse changes in high-flow and low-flow conditions, respectively. Lastly, we fitted discharge data to suitable extreme value distributions to investigate the magnitude and frequency of extreme high flows and low flows. Yearly peak river discharges data were fitted to the generalized extreme value distribution (Stedinger et al., 1993; Dung et al., 2015). Similarly, maximum cumulative discharge deficit, defined as the total deficit under a threshold, were fitted to the generalized Pareto distribution (Tallaksen et al., 2004; Hurkmans et al., 2010) to analyse extreme low flows. The threshold to calculate cumulative discharge deficit is defined as $Q_{75}$ (discharge value exceeded $75 \%$ of the time) under future climate change (Hisdal et al., 2004). Hydrological changes were calculated under individual scenarios and under ensembles, i.e. average changes from multiple GCMs and both RCPs.

\section{Results}

\subsection{Performance of the hydrological simulations}

The calibration and validation results are presented in Table 2 . The simulated river discharges in general match relatively well to the observed data. The NSE values show very good performance $(0.88-0.96)$ for all considered stations. Similarly, the relative biases in total discharge, and the high-flow $\left(Q_{5}\right)$ and low-flow $\left(Q_{95}\right)$ indices are all within acceptable ranges, except for relatively lower performance at the most upstream Chiang Saen station. Discharge biases show underestimation of annual discharge at Chiang Saen by 10 and $12 \%$ during the calibration and validation, respectively. This underestimation is also shown by the flow duration curve, where simulated low flows exhibit more biases than high flows (Fig. 2). Low-flow biases at Chiang Saen could be explained by unaccounted flow regulation by upstream hydropower dams during the dry season, as suggested by Adamson (2001), Lauri et al. (2012) and Räsänen et al. (2012). Lower accuracy of the APHRODITE precipitation data above Chiang Saen could also affect the model's performance. Rainfall data quality is probably affected by strong orographic effects and by a relatively low rain gauge density in this area (Lauri et al., 2014). Discharge biases, however, are only substantial at Chiang Saen station and quickly improve further downstream (see Table 2). Lastly, daily discharge plots also show good matches between simulated and observed discharges for both calibration and validation periods (Fig. 2). Based on these validations, we conclude that the model set-up is suitable for our modelling purposes. 
Table 2. Model performance indices calculated from daily time series for calibration (C) and validation (V) periods. See station locations in Fig. 1.

\begin{tabular}{|c|c|c|c|c|c|c|c|c|}
\hline \multirow[t]{2}{*}{ Stations } & \multicolumn{2}{|c|}{ NSE } & \multicolumn{2}{|c|}{$\begin{array}{l}\text { Relative } \\
\text { total bias }\end{array}$} & \multicolumn{2}{|c|}{$\begin{array}{l}Q_{5} \text { high-flow } \\
\text { relative bias }\end{array}$} & \multicolumn{2}{|c|}{$\begin{array}{l}Q_{95} \text { low-flow } \\
\text { relative bias }\end{array}$} \\
\hline & $\mathrm{C}$ & V & $\mathrm{C}$ & V & $\mathrm{C}$ & V & $\mathrm{C}$ & $\mathrm{V}$ \\
\hline Chiang Saen & 0.90 & 0.90 & 0.90 & 0.88 & 0.93 & 0.91 & 0.64 & 0.62 \\
\hline Vientiane & 0.92 & 0.88 & 1.08 & 1.10 & 1.12 & 1.14 & 0.85 & 0.81 \\
\hline Nakhon Phanom & 0.96 & 0.96 & 1.03 & 1.03 & 1 & 0.85 & 0.92 & 0.72 \\
\hline Mukdahan & 0.96 & 0.95 & 0.98 & 1 & 0.96 & 0.89 & 0.81 & 0.7 \\
\hline Pakse & 0.94 & 0.94 & 0.94 & 0.91 & 0.88 & 0.88 & 0.89 & 0.82 \\
\hline Stung Treng & 0.94 & 0.97 & 0.93 & 0.89 & 0.86 & 0.84 & 1.09 & 0.86 \\
\hline Kratie & 0.95 & 0.93 & 1.00 & 0.90 & 0.91 & 0.85 & 1.01 & 0.83 \\
\hline
\end{tabular}
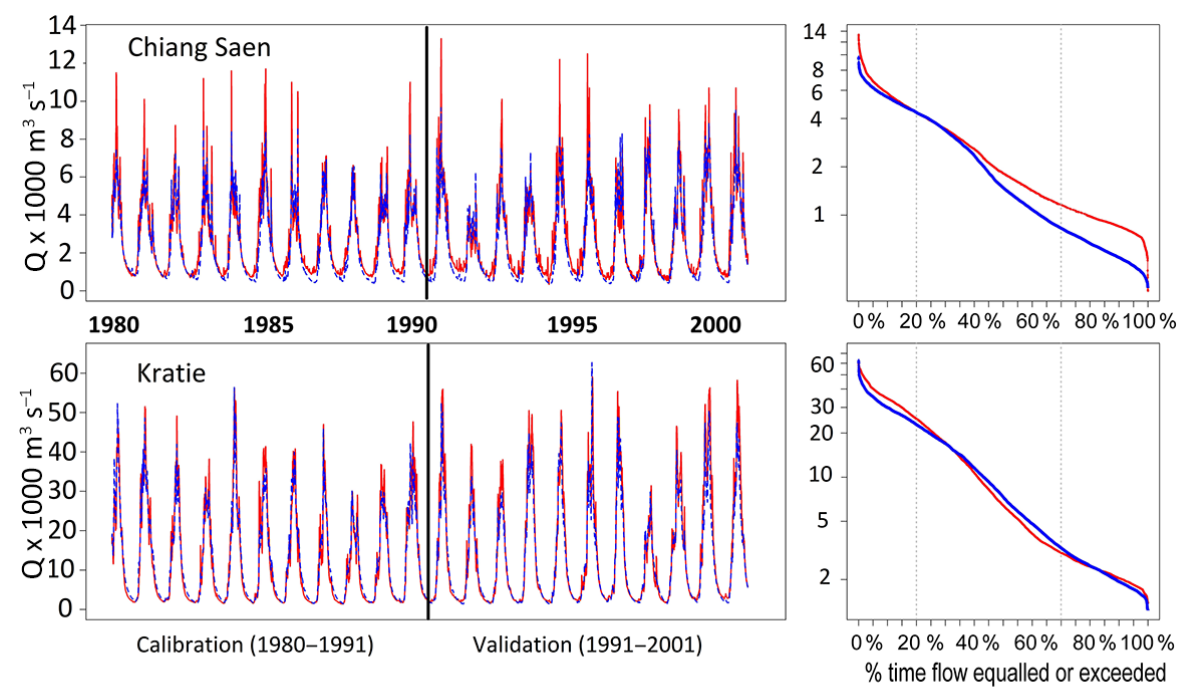

\section{Observed discharge Simulated discharge}

Figure 2. Daily discharge plots (left panels) and flow duration curves (right panels) during calibration and validation at Chiang Saen (upper panels) and Kratie (lower panels). See station locations in Fig. 1.

\subsection{Climate change projection}

We analysed future changes in temperature and precipitation projected by the GCMs and RCPs by comparing climate data between the baseline (1971-2000) and future (2036-2065) periods. Since we only assessed hydrological changes down to Kratie (Cambodia), we excluded the downstream area below this station (i.e. south of latitude $12.5^{\circ} \mathrm{N}$ ) when calculating temperature and precipitation changes.

Overall, surface air temperature increases consistently under all GCMs and RCPs (Fig. 3). All GCMs project higher temperature increase in the RCP8.5 than in the RCP4.5. In particular, the RCP8.5 ensemble shows an increase of $+2.4{ }^{\circ} \mathrm{C}$, whereas the RCP4.5 ensemble projects $+1.9^{\circ} \mathrm{C}$. Temperature increase differs amongst the individual GCMs and RCPs. The lowest basin-average temperature increase of $1.5^{\circ} \mathrm{C}$ is projected by the MPI-RCP4.5, whereas the
ACCESS-RCP8.5 projects the highest increase of $3.5^{\circ} \mathrm{C}$. A majority of scenarios project temperature increases between 1.5 and $2.5^{\circ} \mathrm{C}$, including CCSM-RCP8.5, CSIRO-RCP4.5, CSIRO-RCP8.5, HadGEM-RCP4.5, HadGEM-RCP8.5, and MPI-RCP4.5. Notably, the ACCESS GCM shows markedly more temperature increase compared to other models. The spatial patterns of temperature increases are relatively similar between the scenarios: temperature tends to increase more in the upper catchment area in China, large parts of Thailand, and sometimes also in the Vietnamese Mekong delta (Fig. 3). Areas with lower future temperature increases are located mostly in the eastern part of the Mekong's lower basin including eastern Cambodia and the central highlands of Vietnam.

Total annual precipitation in the Mekong basin is projected to increase under most (i.e. 9 out of 10) climate change scenarios. Only the HadGEM-RCP8.5 scenario projects a slight 
RCP 4.5
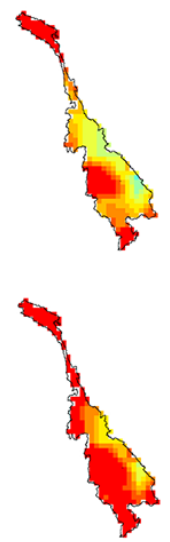

ACCESS
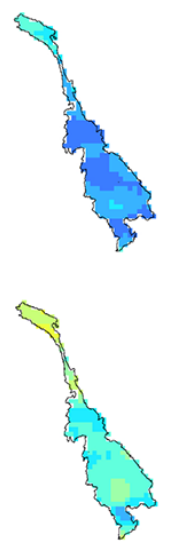

CCSM

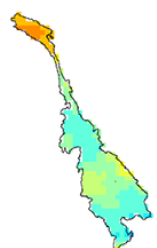

RCP 8.5

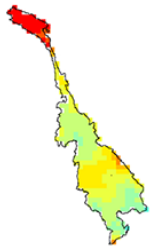

CSIRO

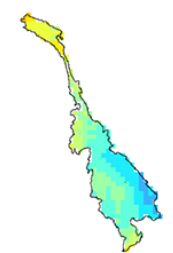

Temperature increase $\left({ }^{\circ} \mathrm{C}\right)$

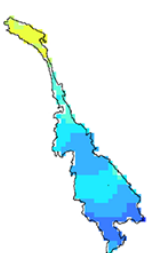

$>3$

$\square 2.8-3$

$\square 2.6-2.8$

$\square$ 2.4-2.6

2.2-2.4

$2-2.2$

1.8-2
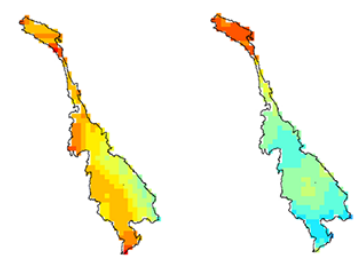

1.6-1.8

1.4-1.6

1.2-1.4

1-1.2

$<1$

Figure 3. Projected change in daily mean temperature $\left({ }^{\circ} \mathrm{C}\right)$ under future climate (2036-2065) compared to baseline situation (1971-2000).
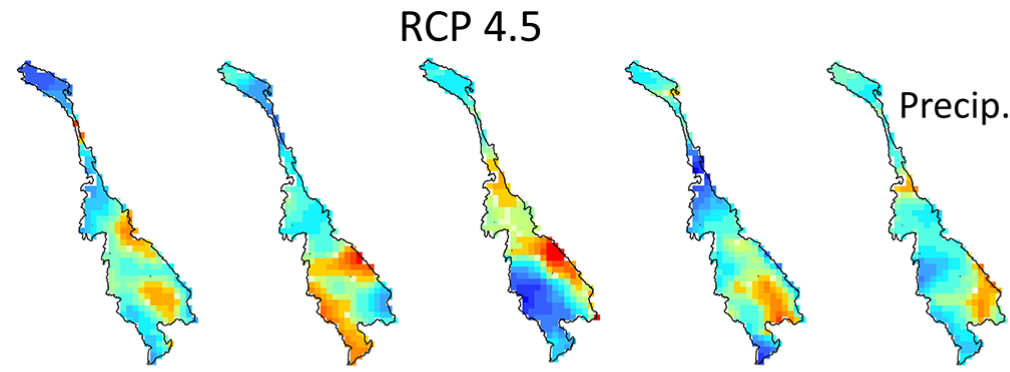

change (\%) 
Table 3. Relative changes in annual river discharges at the Mekong's mainstream stations for 2036-2065 relative to 1971-2000. The lowest and highest changes are presented with the corresponding climate change scenarios.

\begin{tabular}{lccccc}
\hline Station & \multicolumn{2}{c}{ RCP4.5 } & & \multicolumn{2}{c}{ RCP8.5 } \\
\cline { 2 - 3 } \cline { 5 - 6 } & $\begin{array}{l}\text { Ensemble } \\
\text { mean }(\%)\end{array}$ & Range $(\%)$ & & $\begin{array}{c}\text { Ensemble } \\
\text { mean }(\%)\end{array}$ & Range $(\%)$ \\
\hline Chiang Saen & +14 & $\begin{array}{c}+4 \text { to }+29 \\
\text { CSIRO }- \text { ACCESS }\end{array}$ & & +15 & $\begin{array}{c}-1 \text { to }+33 \\
\text { CSIRO }- \text { ACCESS }\end{array}$ \\
\hline Vientiane & +9 & $\begin{array}{c}+1 \text { to }+17 \\
\text { CSIRO }- \text { ACCESS }\end{array}$ & +9 & $\begin{array}{c}-1 \text { to }+20 \\
\text { CSIRO }- \text { ACCESS }\end{array}$ \\
\hline Nakhon Phanom & +7 & $\begin{array}{c}-1 \text { to }+12 \\
\text { CSIRO }- \text { ACCESS }\end{array}$ & +6 & $\begin{array}{c}-2 \text { to }+13 \\
\text { CSIRO }- \text { ACCESS }\end{array}$ \\
\hline Mukdahan & +6 & $\begin{array}{c}-1 \text { to }+11 \\
\text { CSIRO }- \text { ACCESS }\end{array}$ & +5 & $\begin{array}{c}-4 \text { to }+13 \\
\text { HadGEM }- \text { ACCESS }\end{array}$ \\
\hline Pakse & +6 & $\begin{array}{c}+2 \text { to }+10 \\
\text { CCSM }- \text { ACCESS }\end{array}$ & +5 & $\begin{array}{c}-6 \text { to }+13 \\
\text { HadGEM }- \text { MPI }\end{array}$ \\
\hline Stung Treng & +5 & $\begin{array}{c}+3 \text { to }+8 \\
\text { CCSM }- \text { ACCESS }\end{array}$ & +5 & $\begin{array}{c}-7 \text { to }+10 \\
\text { HadGEM }- \text { ACCESS }\end{array}$ \\
\hline Kratie & +5 & $\begin{array}{c}+3 \text { to }+8 \\
\text { CCSM }- \text { ACCESS }\end{array}$ & +5 & $\begin{array}{c}-7 \text { to }+11 \\
\text { HadGEM }- \text { MPI }\end{array}$ \\
\hline
\end{tabular}

Table 4. Comparing projected precipitation and discharge changes across studies.

\begin{tabular}{|c|c|c|c|c|c|}
\hline & $\begin{array}{l}\text { Eastham et al. } \\
\text { (2008) }\end{array}$ & $\begin{array}{l}\text { Kingston et al. } \\
\text { (2011) }\end{array}$ & Lauri et al. (2012) & $\begin{array}{l}\text { Thompson et al. } \\
\text { (2013) }\end{array}$ & $\begin{array}{l}\text { Hoang et al. } \\
\text { (2016) (this } \\
\text { study) }\end{array}$ \\
\hline $\begin{array}{l}\text { Range of } \\
\text { annual } \\
\text { precipitation } \\
\text { change }\end{array}$ & $\begin{array}{l}0.5 \text { to } 36 \% \\
\text { (A1B) }\end{array}$ & $\begin{array}{l}-3 \text { to } 10 \%\left(2{ }^{\circ} \mathrm{C}\right. \\
\text { warming })\end{array}$ & $\begin{array}{l}1.2 \text { to } 5.8 \% \\
\text { (B1) } \\
-2.5 \text { to } 8.6 \% \\
\text { (A1B) }\end{array}$ & $\begin{array}{l}-3 \text { to } 12.2 \%\left(2{ }^{\circ} \mathrm{C}\right. \\
\text { warming })\end{array}$ & $\begin{array}{l}3 \text { to } 4 \% \\
\text { (RCP4.5) } \\
-3 \text { to } 5 \% \\
\text { (RCP8.5) }\end{array}$ \\
\hline $\begin{array}{l}\text { Scenarios } \\
\text { projecting } \\
\text { higher annual } \\
\text { precipitation }\end{array}$ & Not available & 4 out of 7 & 9 out of 10 & 4 out of 7 & 9 out of 10 \\
\hline $\begin{array}{l}\text { Range of } \\
\text { annual } \\
\text { discharge } \\
\text { change }\end{array}$ & Not available & $\begin{array}{l}-17.8 \text { to } 6.5 \% \\
\text { (at Pakse, } 2^{\circ} \mathrm{C} \\
\text { warming) }\end{array}$ & $\begin{array}{l}-6.9 \text { to } 8.1 \% \\
\text { (B1) } \\
-10.6 \text { to } 13.4 \% \\
\text { (A1B) }\end{array}$ & $\begin{array}{l}-14.7 \text { to } 8.2 \% \\
\left(2{ }^{\circ} \mathrm{C} \text { warming }\right)\end{array}$ & $\begin{array}{l}3 \text { to } 8 \% \\
\text { (RCP4.5) } \\
-7 \text { to } 11 \% \\
\text { (RCP8.5) }\end{array}$ \\
\hline $\begin{array}{l}\text { Scenarios } \\
\text { projecting } \\
\text { higher annual } \\
\text { discharge }\end{array}$ & $\begin{array}{l}\text { Majority of } \\
\text { GCMs show } \\
\text { increasing } \\
\text { trend }\end{array}$ & 3 out of 7 & 7 out of 10 & 3 out of 7 & 9 out of 10 \\
\hline
\end{tabular}

\subsection{Changes in the flow regime}

This section presents changes in annual, seasonal, and monthly river discharges under climate change. Annual changes are presented for all seven mainstream stations (see locations in Fig. 1) while we limit the rest of the results to three representative stations to maintain the paper's focus.
These stations are Vientiane (Laos PDR), Mukdahan (Thailand), and Kratie (Cambodia), each representing the upper, middle, and lower parts of the basin, respectively.

The GCM ensemble mean, lowest, and highest changes in annual river discharge are presented in Table 3 for both RCPs. The ensemble means in both the RCP4.5 and the RCP8.5 show a general increase of the Mekong's mean flow 
under climate change. Annual discharges increase between $+5 \%$ (at Kratie and Stung Treng) and $+15 \%$ (at Chiang Saen), indicating a more substantial increase in the upstream stations compared to the downstream ones. Despite the general increasing signal based on ensemble mean, annual discharges also reduce slightly under some individual scenarios. The reductions range from $-1 \%$ (at Chiang Saen, scenario CSIR0-RCP4.5) to $-7 \%$ (at Stung Treng and Kratie, scenario HadGEM-RCP8.5). While the ensemble means under the two RCPs are very similar, the RCP 8.5 exhibits a larger range in projected discharge changes (Table 3). This larger range is associated with more differentiated precipitation changes under individual GCMs in the RCP8.5 compared to those in the RCP4.5 (see Fig. 4).

Figure 5 shows changes in monthly river discharges under climate change. Overall, the scenario ensembles show higher monthly river flow at all considered stations, except for a slight reduction in June. Absolute discharge increases are more substantial in the wet season compared to those in the dry season. In terms of timing, the RCP4.5 shows the largest increases in November, while the RCP8.5 shows the largest increase in August. Although absolute increases are more substantial during the wet season months, relative increases are higher during the dry season. For instance, discharge in April could increase up to $+40 \%\left(+360 \mathrm{~m}^{3} \mathrm{~s}^{-1}\right)$ at Vientiane and $+25 \%\left(+480 \mathrm{~m}^{3} \mathrm{~s}^{-1}\right)$ at Kratie. Despite the overall increasing trends, discharge in June is projected to reduce slightly at all three stations, ranging between $-810 \mathrm{~m}^{3} \mathrm{~s}^{-1}$ $(-8 \%)$ at Kratie, followed by $-530 \mathrm{~m}^{3} \mathrm{~s}^{-1}(-8 \%)$ at Mukdahan and $-210 \mathrm{~m}^{3} \mathrm{~s}^{-1}(-5 \%)$ at Vientiane. On the seasonal timescale, discharges increase at all stations during both the wet and dry seasons.

Cross-GCM comparisons show that monthly discharge changes during the wet season are more variable compared to the dry season. Figure 5 clearly shows that the ensemble's projection ranges become markedly larger in the wet season, implying higher uncertainty in the hydrological change signal. For example, projected river discharge in August at Mukdahan ranges between $15400 \mathrm{~m}^{3} \mathrm{~s}^{-1}$ (scenario HadGEMRCP8.5) and $22300 \mathrm{~m}^{3} \mathrm{~s}^{-1}$ (scenario MPI-RCP8.5). This is a spread of $6900 \mathrm{~m}^{3} \mathrm{~s}^{-1}$, equivalent to $36 \%$ of the average discharge in August. Moreover, the individual GCMs also show contrasting directional discharge changes in the wet season months. The CSIRO and HadGEM models project reductions in discharge during June-October, whereas the other models project discharge increases during the same period. These contrasting directional changes mainly result from the disagreement among GCMs on the future precipitation regime in the Mekong basin. This disagreement highlights one of the key uncertainties in projecting future climatic change and subsequently hydrological responses in the Mekong basin, as also noted by Kingston et al. (2011).

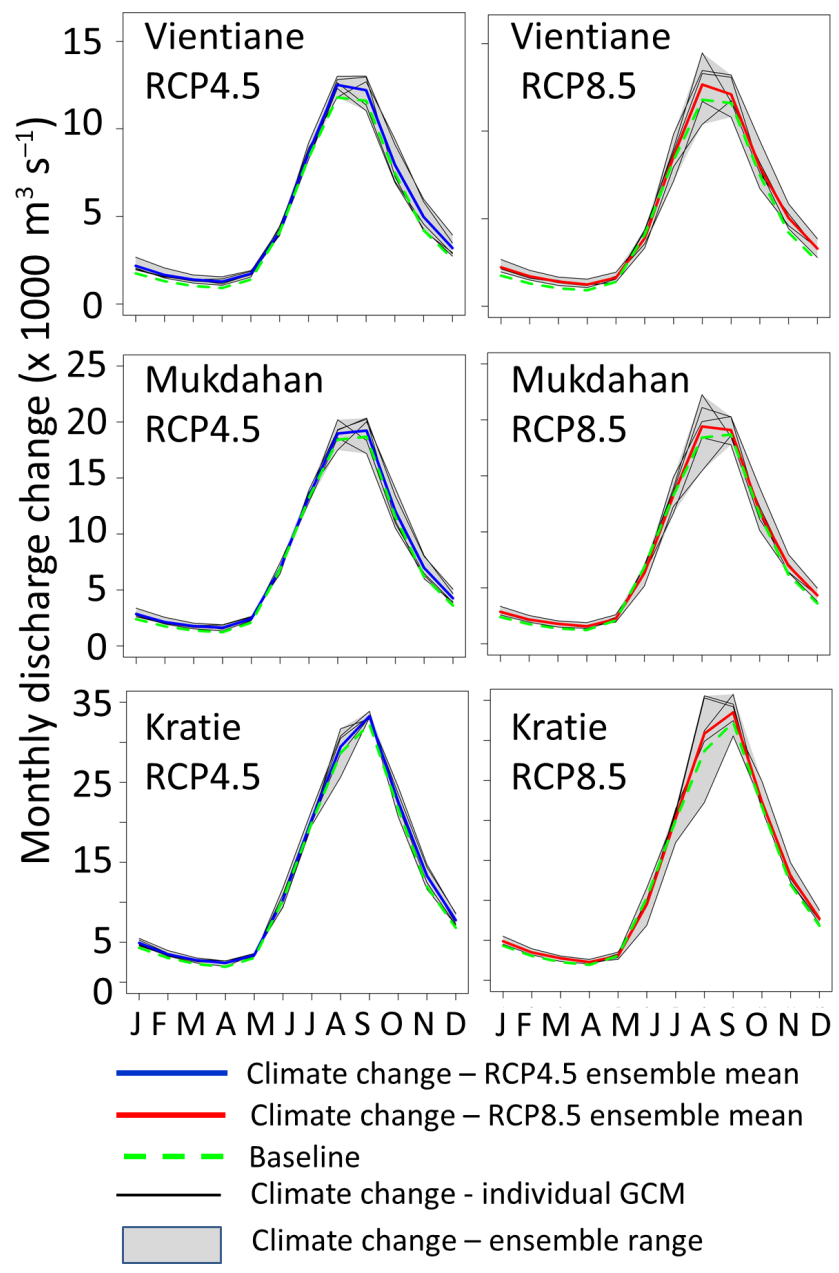

Figure 5. Projected monthly river discharge under climate change for 2036-2065 relative to 1971-2000.

\subsection{Changes in hydrological extremes}

This section subsequently presents changes in $Q_{5}$ (high flow), $Q_{95}$ (low flow), and hydrological extremes. Relative changes in high flows $\left(Q_{5}\right)$ and low flows $\left(Q_{95}\right)$ at Vientiane, Mukdahan, and Kratie are shown in Fig. 6. Overall, high flows are projected to increase at all considered stations. The scenario ensemble means show increases in $Q_{5}$ of +8 , +5 , and $+6 \%$ at Vientiane, Mukdahan, and Kratie, respectively. However, high flows also slightly reduce in two scenarios. In particular, the CSIRO-RCP8.5 projects high-flow reduction at Vientiane $(-6 \%)$ and Mukdahan $(-3 \%)$. Similarly, the HadGEM-RCP8.5 also suggests reductions of -1 , -2 , and $-4 \%$ of high flows at Vientiane, Mukdahan, and Kratie, respectively. Low flows are projected to increase under all considered scenarios, implying more water availability during the dry season. On average, $Q_{95}$ increases most substantially at Vientiane $(+41 \%)$, followed by Mukdahan $(+30 \%)$ and Kratie $(+20 \%)$. 


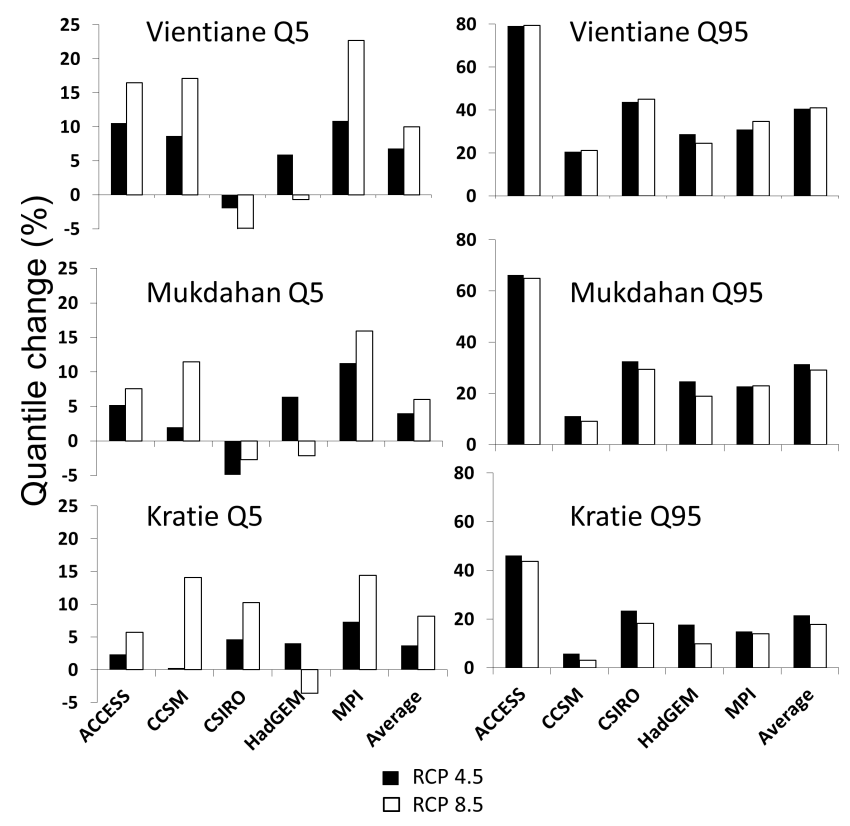

Figure 6. Projected changes in $Q_{5}$ (high flow) and $Q_{95}$ (low flow) under climate change for 2036-2065 relative to 1971-2000.

The non-exceedance curves of yearly peak discharges (Fig. 7) show substantial increases in extremely high flow at all considered stations. The baseline's non-exceedance curves are always lower than those from the GCM ensemble means, implying increases in both the magnitude and frequency of annual peak flows. At Vientiane, for instance, the maximum river discharge occurring once every 10 years is projected to increase from 23800 to $27900 \mathrm{~m}^{3} \mathrm{~s}^{-1}$ (RCP4.5) and $28500 \mathrm{~m}^{3} \mathrm{~s}^{-1}$ (RCP8.5). Similarly, yearly peak discharges at Kratie increase from 61700 to $65000 \mathrm{~m}^{3} \mathrm{~s}^{-1}$ (RCP4.5) and $66900 \mathrm{~m}^{3} \mathrm{~s}^{-1}$ (RCP8.5).

Lastly, both magnitude and frequency of extremely low flows are projected to reduce due to more water availability during the dry season. Higher dry season discharge results in reductions in the total discharge deficits, defined as the total deficit under a threshold ( $Q_{75}$ value under climate change). The non-exceedance curves in Fig. 8 shows that these deficits reduce substantially at all three representative stations. Discharge deficits are lowest at Vientiane, ranging between $68,000 \mathrm{~m}^{3} / \mathrm{s}$ (2-year return period) and $100000 \mathrm{~m}^{3} \mathrm{~s}^{-1}$ (20-year return period) under the baseline condition. These deficits are projected to reduce by almost $50 \%$, to 30000 and $58000 \mathrm{~m}^{3} \mathrm{~s}^{-1}$ under the RCP8.5 scenario. Similarly, discharge deficits also reduce substantially at Mukdahan and Kratie. Figure 8 also shows that future discharge deficits are relatively similar between the RCP4.5 and the RCP8.5.

\section{Discussion}

We have presented climatic and hydrological changes in the Mekong River basin based on a relatively large ensemble of CMIP5 GCMs and climate change scenarios. Motivated by improvements in CMIP5 GCMs technicalities and performance, we further analysed changes in extreme hydrological conditions under climate change. As such, our results provide important updates and new insights to the current knowledge base about hydrological response to climate change. Additionally, the results also reveal important implications for water resources management and climate change adaptation.

\subsection{Comparison: impact signal and improvements in uncertainties}

Our results further confirm and solidify the Mekong's hydrological intensification in response to climate change (Sect. 4.3 and 4.4). In general, hydrological impact signals from the CMIP5 scenarios are in line with findings from most previous CMIP3-based studies. This study projects an increase of $+5 \%$ in average annual river discharge at Kratie, compared to $+10,+4$, and $+3 \%$ by Hoanh et al. (2010), Västilä et al. (2010), and Lauri et al. (2012), respectively. Similar to these studies, our results also show increasing monthly and seasonal river discharges. Despite the differences in GCMs choices, climate experiment generations (i.e. CMIP5 versus CMIP3), and downscaling approaches, the increasing trend in annual and seasonal river flow is robust across different studies. Therefore, certain confidence can be placed on the general direction of the Mekong's hydrological change under climate change.

Furthermore, the projected impact signals in this study exhibit less uncertainty compared to similar CMIP3-based assessments. A cross-study comparison (see Table 4) for the representative Kratie station shows that both the impact signal's range and cross-scenarios agreement on directional changes improved markedly in this CMIP5-based study. In particular, the ranges of annual discharge change, i.e. 3 to $8 \%$ (RCP4.5) and -7 to $11 \%$ (RCP8.5), are typically smaller than those projected by earlier studies including Eastham et al. (2008), Kingston et al. (2011), Lauri et al. (2012) and Thompson et al. (2013). Similarly, the projected precipitation changes also show less uncertainty in the CMIP5 scenarios compared to the CMIP3 scenarios. Additionally, directional discharge changes also show better consensus in this study. The CMIP5-based ensemble's impact signal (i.e. increasing annual discharge) is supported by 9 out of 10 individual scenarios, whereas other studies show relatively lower consensus. Lastly, we compared uncertainty in hydrological extremes by calculating the coefficient of variation for projected yearly peak discharges between studies. Due to limited data availability, we only compared our study with Lauri et al. (2012). Both studies have ensembles of 10 projections, grouped into a mid-range scenario (i.e. RCP4.5 versus 

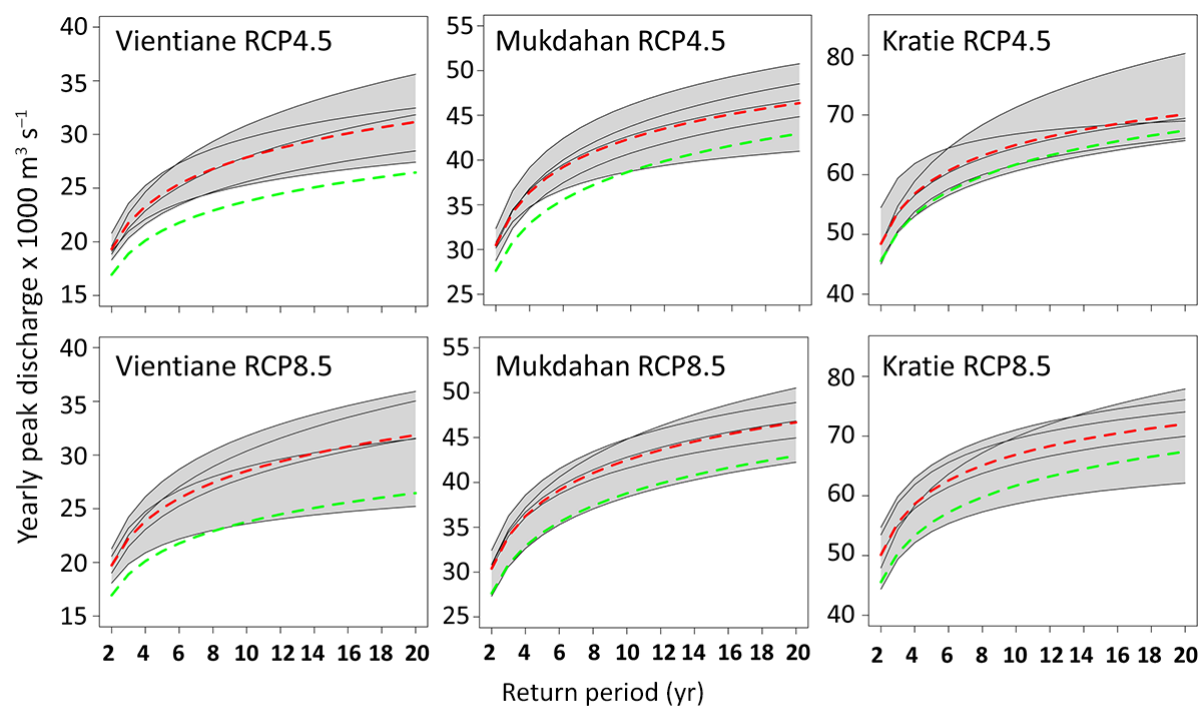

- - - Climate change - ensemble mean

-.... Baseline

Climate change - individual GCM

Climate change - ensemble range

Figure 7. Non-exceedance curves of yearly peak discharges under baseline (1971-2000) and future climate (2036-2065).
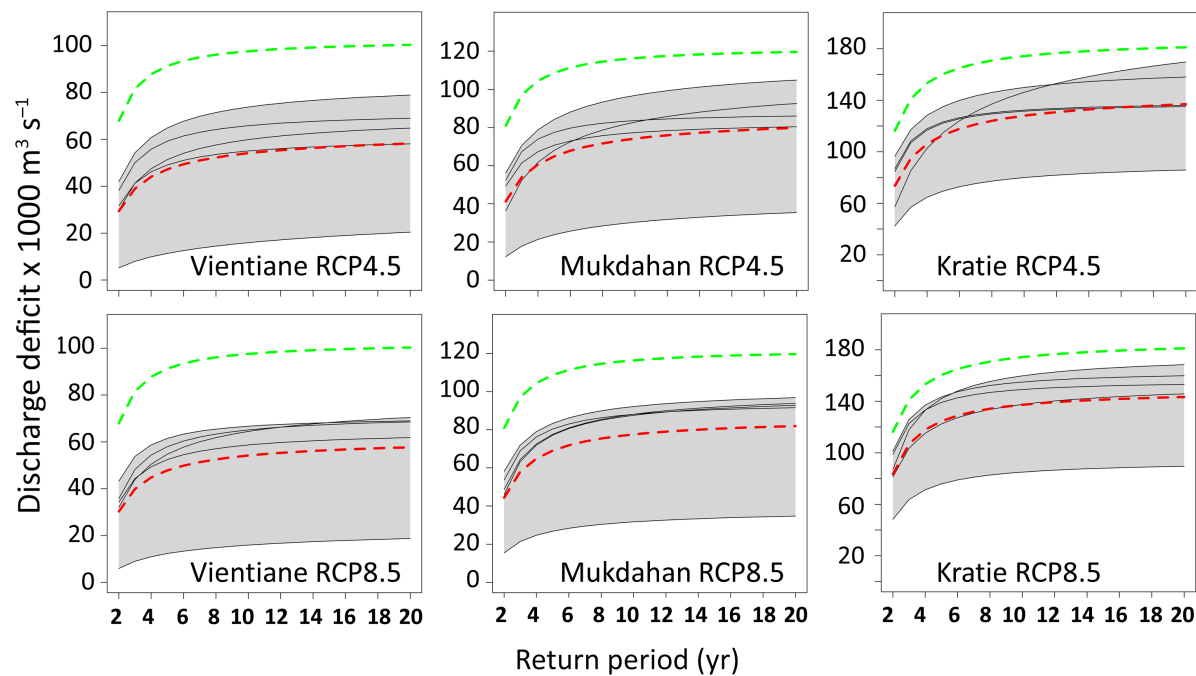

$-\ldots$ Climate change - ensemble mean
$\square$ Climate change - individual GCM
$\square$ Climate change - ensemble range

Figure 8. Non-exceedance curves of yearly maximum cumulative discharge deficits (i.e. total deficit below the $Q_{75}$ threshold) under baseline and future climate.

SRES-B1) and a high scenario (i.e. RCP8.5 versus SRESA1B). Overall, our CMIP5-based projection exhibits lower uncertainty, shown by lower coefficients of variation for both the mid-range scenarios ( $24 \%$ vs. $38 \%)$ and the high scenario $(25 \%$ vs. $38 \%)$. Reduced uncertainty detected in our study is also in line with studies by Sperber et al. (2013) and
Hasson et al. (2016), where they found improved representations of the Asian summer monsoon with the CMIP5 models.

\subsection{Implications for water management}

Projected hydrological changes, especially increases in highflow and low-flow conditions under climate change show im- 
portant implications for water management in the river basin. First, higher peak discharges occurring at higher frequencies during the wet season will increase the flood risks across the basin. Higher flood risks will be particularly relevant for human safety and agricultural production in the lower Mekong region, including the Cambodian and Vietnamese delta. Vast agriculture areas along the main rivers and in the delta's floodplain will likely experience higher flood water levels, thus having higher risks of reduced productivity and crop failure. Higher river flow, combined with sea level rise will also result in higher flood risks for urban areas in the Mekong Delta.

Second, increased water availability during the dry season suggested by the $Q_{95}$ and discharge deficit analyses can have positive implications. The projected higher river discharge during the dry season months could help to mitigate water shortage in the basin. Higher dry season flow will also contribute to control salt water intrusion in the Vietnamese Mekong delta, where fresh water flow from upstream is currently used to control the salt gradient in rivers and canals in the coastal area. Additionally, projected discharge reduction at the beginning of the wet season (i.e. in June) probably has negative impacts on ecological and agricultural productivity. Flow alteration in the early wet season will likely change the sediment and nutrient dynamics in the downstream floodplains, which are very important for existing ecosystems and agricultural practices (Arias et al., 2012). Lastly, rainfall reduction in some areas of the lower Mekong could damage agricultural production, especially rainfed agriculture.

\subsection{Limitations and way forward}

We acknowledge several limitations and potential sources of error in this research. First, combining two historic climate data sets (i.e. the WATCH and the APHRODITE) may introduce errors due to inconsistencies. However, our data set selection is motivated by careful consideration of data quality and availability. Although APHRODITE provides high quality precipitation data (Vu et al., 2012; Lauri et al., 2014), this data set lacks temperature data needed for the hydrological model. We therefore supplement temperature data from the commonly used WATCH Forcing Data. Furthermore, calibration and validation results show that our hydrological simulation based on the combined climate forcing data is able to realistically reproduce historic river discharge. Given relatively lower modelling skill at Chiang Saen, interpreting the hydrological impact signal at this station requires extra caution. Combinations of temperature and precipitation data sets were also shown by Lauri et al. (2014) to yield sufficient accuracy in hydrological modelling in the Mekong basin. Second, this paper only uses one bias-correction method (i.e. Piani et al., 2010) for climate data preparation. This could affect the derived hydrological impact signal (Hagemann et al., 2011) but is unlikely to change the main signal of hydrological change. Additionally, including other bias- correction methods is outside this paper's scope given our primary interest to understand how the Mekong's hydrology will change under climate change. Third, due to limited data availability, we could not include climate change projections from regional climate models (e.g. CORDEX) in our study. Such inclusion of such high-resolution climate projections could be useful, not only for this study, but also for the current knowledge base about the Mekong's hydrology under climate change. The scope of this study is to understand how climate change will affect Mekong's hydrology including extremes. Hydrological changes, however, are simultaneously driven by multiple factors including irrigated land expansion, urbanization, hydropower dams, and interbasin water transfer. For example, several studies, including Lauri et al. (2012), Piman et al. (2013), and MRC (2011a), have shown that irrigation expansion, hydropower dam construction, and water transfer projects can largely alter flow regime. Such anthropogenic factors should be subjected to future studies in order to yield more comprehensive insights about the Mekong's future hydrology and water resources. Of special importance in this regard is the need to assess the interactions between different drivers and the resulted hydrological changes.

\section{Conclusions}

This study is one of the first hydrological impact assessments for the Mekong River basin focusing on hydrological extremes under climate change. We aim to cover this particularly important knowledge gap, and thereby better supporting policy and decision making in Southeast Asia's largest river basin.

Climate change scenarios show that temperature consistently increases across the basin, with higher rises in the upper basin in China, large parts of Thailand and the Vietnamese Mekong delta. Basin-wide precipitation also increases under a majority of scenarios ( 9 out of 10), but certain areas also exhibit reducing signal. As a result, the Mekong's hydrology will intensify, characterized by increases in annual river discharge at all stations. The scenario ensemble means also show increases in seasonal discharges, for both wet and dry seasons. Discharge increases are more substantial during the wet season, but the ensemble ranges are more variable compared to the dry season. Considerably different and sometimes contrasting directional discharge changes exist in our scenarios ensemble. This uncertainty, although reduced markedly compared to earlier CMIP3-based assessments, highlights a challenge in quantifying future hydrological change. It emphasizes the importance of, first, using ensemble approach in hydrological assessments, and second developing robust, adaptive approaches to water management under climate change.

Lastly, we found substantial changes in hydrological extremes concerning both low-flow and high-flow conditions. 
Water availability during dry season increases under all climate change scenarios, suggesting positive impacts on water supply and salinization control in the downstream delta. Wet season discharges and annual peak flows will increase substantially, implying important consequences for risk management, especially in securing safety of water infrastructures, and in controlling flood risks in the Mekong Delta. Given robust evidences of changes in hydrological extremes, shifting research and management focuses to these low-probability but potentially highly damaging events is important to reduce climate change impacts and associated risks.

\section{The Supplement related to this article is available online at doi:10.5194/hess-20-3027-2016-supplement.}

Acknowledgements. We would like to thank our colleagues at the Water Systems and Global Change Group, especially Wietse Franssen, and Chu Thai Hoanh (at IWMI) for their useful supports and suggestions. Long Phi Hoang received funding from the Dutch-Vietnamese Mekong Delta Plan project. Matti Kummu received funding from Academy of Finland project SCART (grant no. 267463) and Emil Aaltonen foundation ("eat-lesswater" project). Michelle van Vliet was financially supported by a Veni-grant (project 863.14.008) of NWO Earth and Life Sciences (ALW). Lastly, we thank the editor and three anonymous reviewers for providing their useful and constructive comments on this paper.

Edited by: F. Tian

Reviewed by: three anonymous referees

\section{References}

Adamson, P. T.: Hydrological perspectives on the Lower Mekong Basin: The potential impacts of hydropower developments in Yunnan on the downstream flow regime, Int. Water Power Dam Constr., 16-21, 2001.

Adamson, P. T., Rutherfurd, I. D., Peel, M. C., and Conlan, I. A.: Chapter 4 - The Hydrology of the Mekong River, in: The Mekong, Academic Press, San Diego, 53-76, doi:10.1016/B9780-12-374026-7.00004-8, 2009.

Arias, M. E., Cochrane, T. A., Piman, T., Kummu, M., Caruso, B. S., and Killeen, T. J.: Quantifying changes in flooding and habitats in the Tonle Sap Lake (Cambodia) caused by water infrastructure development and climate change in the Mekong Basin, J. Environ. Manage., 112, 53-66, 2012.

Arias, M. E., Cochrane, T. A., Kummu, M., Lauri, H., Holtgrieve, G. W., Koponen, J., and Piman, T.: Impacts of hydropower and climate change on drivers of ecological productivity of Southeast Asia's most important wetland, Ecol. Model., 272, 252-263, doi:10.1016/j.ecolmodel.2013.10.015, 2014.

Cosslett, T. and Cosslett, P.: Major Threats to Mekong Delta: Climate Change and Mainstream Dams, in: Water Resources and Food Security in the Vietnam Mekong Delta, vol. 44, Natural Resource Management and Policy, Springer International Publish- ing, Cham, Heidelberg, New York, Dordrecht, London, 75-96, doi:10.1007/978-3-319-02198-0_3, 2014.

Costa-Cabral, M. C., Richey, J. E., Goteti, G., Lettenmaier, D. P., Feldkötter, C., and Snidvongs, A.: Landscape structure and use, climate, and water movement in the Mekong River basin, Hydrol. Process., 22, 1731-1746, doi:10.1002/hyp.6740, 2008.

Dai, A. and Trenberth, K. E.: Estimates of Freshwater Discharge from Continents: Latitudinal and Seasonal Variations, J. Hydrometeorol., 3, 660-687, doi:10.1175/15257541(2002)003<0660:eofdfc >2.0.co;2, 2002.

Delgado, J. M., Merz, B., and Apel, H.: A climate-flood link for the lower Mekong River, Hydrol. Earth Syst. Sci., 16, 1533-1541, doi:10.5194/hess-16-1533-2012, 2012.

Dingman, S. L.: Water in soils: infiltration and redistribution, in: Physical hydrology, Vol. 575, Englewood Cliffs, Prentice Hall, NJ, 1994.

Dung, N. V., Merz, B., Bárdossy, A., and Apel, H.: Handling uncertainty in bivariate quantile estimation - an application to flood hazard analysis in the Mekong Delta, J. Hydrol., 527, 704-717, 2015.

Eastham, J., Mpelasoka, F., Mainuddin, M., Ticehurst, C., Dyce, P., Hodgson, G., Ali, R., and Kirby, M.: Mekong River Basin water resources assessment: Impacts of climate change, Water for a Healthy Country National Research Flagship report, CSIRO, 2008.

FAO: WRB map of world soil resources, Food and Agriculture Organization of United Nations (FAO), Land and Water Development Division, Rome, 2003.

Giorgi, F. and Gutowski Jr., W. J.: Regional Dynamical Downscaling and the CORDEX Initiative, Annu. Rev. Environ. Resour., 40, 467-490, doi:10.1146/annurev-environ-102014021217, 2015.

GLC2000: Global Land Cover 2000 database, European Commission, Joint Research Centre, http://forobs.jrc.ec.europa.eu/ products/glc2000/glc2000.php (last access: July 2016), 2003.

Hagemann, S., Chen, C., Haerter, J. O., Heinke, J., Gerten, D., and Piani, C.: Impact of a Statistical Bias Correction on the Projected Hydrological Changes Obtained from Three GCMs and Two Hydrology Models, J. Hydrometeorol., 12, 556-578, doi:10.1175/2011JHM1336.1, 2011.

Hargraeves, G. H. and Samani, Z. A.: Estimating potential evapotranspiration, J. Irrig. Drain. Divis.-ASCE, 108, 225-230, 1982.

Hasson, S., Pascale, S., Lucarini, V., and Böhner, J.: Seasonal cycle of precipitation over major river basins in South and Southeast Asia: A review of the CMIP5 climate models data for present climate and future climate projections, Atmos. Res., doi:10.1016/j.atmosres.2016.05.008, in press, 2016.

Hisdal, H., Tallaksen, L. M., Clausen, B., Peters, E., and Gustard, A.: Hydrological drought characteristics in: Hydrological Drought: Processes and Estimation Methods for Streamflow and Groundwater, Elsevier, Amsterdam, Boston, Heidelberg, London, New York, Oxford, Paris, San Diego, San Francisco, Singapore, Sydney, Tokyo, 139-198, 2004.

Hoanh, C. T., Jirayoot, K., Lacombe, G., and Srinetr, V.: Impacts of climate change and development on Mekong flow regime, First assessment - 2009, MRC Technical Paper No. 29, Mekong River Commission, Vientiane, Lao PDR, 2010.

Huang, Y., Wang, F., Li, Y., and Cai, T.: Multi-model ensemble simulation and projection in the climate change in the Mekong River 
Basin, Part I: temperature, Environ. Monit. Assess., 186, 75137523, doi:10.1007/s10661-014-3944-x, 2014.

Hurkmans, R., Terink, W., Uijlenhoet, R., Torfs, P., Jacob, D., and Troch, P. A.: Changes in streamflow dynamics in the Rhine basin under three high-resolution regional climate scenarios, J. Climate, 23, 679-699, 2010.

Jacobs, J. W.: The Mekong River Commission: transboundary water resources planning and regional security, Geograph. J., 168, 354364, doi:10.1111/j.0016-7398.2002.00061.x, 2002.

Jarvis, A., Reuter, H., Nelson, A., and Guevara, E.: Hole-filled SRTM for the globe Version 4, CGIAR-CSI SRTM $90 \mathrm{~m}$ Database, CGIAR, 2008.

Keskinen, M., Chinvanno, S., Kummu, M., Nuorteva, P., Snidvongs, A., Varis, O., and Västilä, K.: Climate change and water resources in the Lower Mekong River Basin: putting adaptation into the context, J. Water Clim. Change, 1, 103-117, doi:10.2166/wcc.2010.009, 2010.

Kingston, D. G., Thompson, J. R., and Kite, G.: Uncertainty in climate change projections of discharge for the Mekong River Basin, Hydrol. Earth Syst. Sci., 15, 1459-1471, doi:10.5194/hess-15-1459-2011, 2011.

Knutti, R. and Sedláček, J.: Robustness and uncertainties in the new CMIP5 climate model projections, Nat. Clim. Change, 3, 369373,2013

Lamberts, D. and Koponen, J.: Flood pulse alterations and productivity of the Tonle Sap ecosystem: a model for impact assessment, Ambio, 37, 178-184, 2008.

Lauri, H., Veijalainen, N., Kummu, M, Koponen, J., Virtanen, M., Inkala, A., and Sark, J.: VMod Hydrological Model Manual, Finnish Environment Institute, EIA Ltd., Helsinki University of Technology, Helsinki, 2006.

Lauri, H., de Moel, H., Ward, P. J., Räsänen, T. A., Keskinen, M., and Kummu, M.: Future changes in Mekong River hydrology: impact of climate change and reservoir operation on discharge, Hydrol. Earth Syst. Sci., 16, 4603-4619, doi:10.5194/hess-164603-2012, 2012.

Lauri, H., Räsänen, T. A., and Kummu, M.: Using Reanalysis and Remotely Sensed Temperature and Precipitation Data for Hydrological Modeling in Monsoon Climate: Mekong River Case Study, J. Hydrometeorol., 15, 1532-1545, doi:10.1175/jhm-d13-084.1, 2014.

Lebel, L., Garden, P., and Imamura, M.: The Politics of Scale, Position, and Place in the Governance of Water Resources in the Mekong Region, Ecol. Soc., 10, 2, 2005.

Leng, G., Tang, Q., and Rayburg, S.: Climate change impacts on meteorological, agricultural and hydrological droughts in China, Global Planet. Change, 126, 23-34, doi:10.1016/j.gloplacha.2015.01.003, 2015.

Mitchell, T. D. and Jones, P. D.: An improved method of constructing a database of monthly climate observations and associated high-resolution grids, Int. J. Climatol., 25, 693-712, doi:10.1002/joc.1181, 2005.

MRC: Overview of the Hydrology of the Mekong Basin, Tech. rep., Mekong River Commission, Vientiane, Laos PDR, 2005.

MRC: The flow of the Mekong, Mekong River Commission, Vientiane, Laos PDR, 2009.

MRC: State of the Basin Report 2010, Mekong River Commission, Vientiane, Lao PDR, 2010.
MRC: Assessment of Basin-wide Development Scenarios: Main Report - Basin Development Plan Programme, Mekong River Commission, Vientiane, Lao PDR, 2011a.

MRC: Hydrometeorological database of the Mekong River Commission, Mekong River Commission, Vientiane, Lao PDR, 2011b.

Nakicenovic, N., Alcamo, J., Davis, G., De Vries, H. J. M., Fenhann, J., Gaffin, S., Gregory, K., Grubler, A., Jung, T. Y., Kram, T., La Rovere, E. L., Michaelis, L., Mori, S., Morita, T., Papper, W., Pitcher, H., Price, L., Riahi, K., Roehrl, A., Rogner, H.-H., Sankovski, A., Schlesinger, M., Shukla, P., Smith, S., Swart, R., Van Rooijen, S., Victor, N., and Dadi, Z.: Emissions Scenarios, in: A Special Report of Working Group III of the Intergovernmental Panel on Climate Change, Cambridge University Press, Cambridge, 2000.

Nash, J. and Sutcliffe, J. V.: River flow forecasting through conceptual models part I - A discussion of principles, J. Hydrol., 10, 282-290, 1970.

Piani, C., Weedon, G. P., Best, M., Gomes, S. M., Viterbo, P., Hagemann, S. and Haerter, J. O.: Statistical bias correction of global simulated daily precipitation and temperature for the application of hydrological models, J. Hydrol., 395, 199-215, doi:10.1016/j.jhydrol.2010.10.024, 2010.

Piman, T., Lennaerts, T., and Southalack, P.: Assessment of hydrological changes in the lower Mekong Basin from BasinWide development scenarios, Hydrol. Process., 27, 2115-2125, doi:10.1002/Hyp.9764, 2013.

Räsänen, T. A., Koponen, J., Lauri, H., and Kummu, M.: Downstream hydrological impacts of hydropower development in the Upper Mekong Basin, Water Resour. Manage., 26, 3495-3513, 2012.

Renaud, F. G., Kuenzer, C., Delgado, J., Merz, B., and Apel, H.: Monsoon Variability and the Mekong Flood Regime, in: The Mekong Delta System, Springer Environmental Science and Engineering, Springer Netherlands, 233-244, doi:10.1007/978-94007-3962-8_9, 2012.

Riahi, K., Rao, S., Krey, V., Cho, C., Chirkov, V., Fischer, G., Kindermann, G., Nakicenovic, N., and Rafaj, P.: RCP 8.5 - A scenario of comparatively high greenhouse gas emissions, Climatic Change, 109, 33-57, doi:10.1007/s10584-011-0149-y, 2011.

Sarkkula, J., Koponen, J., Lauri, H., and Virtanen, M.: IWRM modelling report, Detailed Modelling Support (DMS), Information and Knowledge Management Programme, Mekong River Commission, Vientiane, Laos PDR, 2010.

Sillmann, J., Kharin, V. V., Zhang, X., Zwiers, F. W., and Bronaugh, D.: Climate extremes indices in the CMIP5 multimodel ensemble: Part 1: Model evaluation in the present climate, J. Geophys. Res.-Atmos., 118, 1716-1733, doi:10.1002/jgrd.50203, 2013.

Smajgl, A., Toan, T. Q., Nhan, D. K., Ward, J., Trung, N. H., Tri, L. Q., Tri, V. P. D., and Vu, P. T.: Responding to rising sea levels in the Mekong Delta, Nat. Clim. Change, 5, 167-174, 2015.

Sperber, K. R., Annamalai, H., Kang, I. S., Kitoh, A., Moise, A., Turner, A., Wang, B., and Zhou, T.: The Asian summer monsoon: an intercomparison of CMIP5 vs. CMIP3 simulations of the late 20th century, Clim. Dynam., 41, 2711-2744, 2013.

Stedinger, J. R., Vogel, R. M., and Foufoula-Georgiou, E.: Frequency analysis of extreme events, in: Handbook of hydrology, edited by: Maidment, D. R., McGraw-Hill, New York, 18.1118.66, 1993. 
Stocker, T. F., Qin, D., Plattner, G.-K., Tignor, M., Allen, S. K., Boschung, J., Nauels, A., Xia, Y., Bex, V., and Midgley, P. M. (Eds.): Climate Change 2013: The Physical Science Basis, in: Contribution of Working Group I to the Fifth Assessment Report of the Intergovernmental Panel on Climate Change, Cambridge University Press, Cambridge, UK and New York, NY, USA, 2013.

Tallaksen, L. M. and van Lanen, H. A. J. (Eds.): Hydrological Drought: Processes and Estimation Methods for Streamflow and Groundwater, in: Developments in Water Science, Vol. 48, Elsevier, Amsterdam, Boston, Heidelberg, London, New York, Oxford, Paris, San Diego, San Francisco, Singapore, Sydney, Tokyo, 579 pp., 2004

Taylor, K. E., Stouffer, R. J., and Meehl, G. A.: An Overview of CMIP5 and the Experiment Design, B. Am. Meteorol. Soc., 93, 485-498, doi:10.1175/bams-d-11-00094.1, 2011.

Thompson, J. R., Green, A. J., Kingston, D. G., and Gosling, S. $\mathrm{N}$ : Assessment of uncertainty in river flow projections for the Mekong River using multiple GCMs and hydrological models, J. Hydrol., 486, 1-30, 2013.

Thomson, A., Calvin, K., Smith, S., Kyle, G. P., Volke, A., Patel, P., Delgado-Arias, S., Bond-Lamberty, B., Wise, M., Clarke, L., and Edmonds, J.: RCP4.5: a pathway for stabilization of radiative forcing by 2100 , Climatic Change, 109, 77-94, doi:10.1007/s10584-011-0151-4, 2011.

Uppala, S. M., Kållberg, P. W., Simmons, A. J., Andrae, U., Bechtold, V. D. C., Fiorino, M., Gibson, J. K., Haseler, J., Hernandez, A., Kelly, G. A., Li, X., Onogi, K., Saarinen, S., Sokka, N., Allan, R. P., Andersson, E., Arpe, K., Balmaseda, M. A., Beljaars, A. C. M., Berg, L. V. D., Bidlot, J., Bormann, N., Caires, S., Chevallier, F., Dethof, A., Dragosavac, M., Fisher, M., Fuentes, M., Hagemann, S., Hólm, E., Hoskins, B. J., Isaksen, L., Janssen, P. A. E. M., Jenne, R., McNally, A. P., Mahfouf, J. F., Morcrette, J. J., Rayner, N. A., Saunders, R. W., Simon, P., Sterl, A., Trenberth, K. E., Untch, A., Vasiljevic, D., Viterbo, P., and Woollen, J.: The ERA-40 re-analysis, Q. J. Roy. Meteorol. Soc., 131, 2961-3012, doi:10.1256/qj.04.176, 2005.

van Vliet, M. T. H., Franssen, W. H. P., Yearsley, J. R., Ludwig, F., Haddeland, I., Lettenmaier, D. P., and Kabat, P. : Global river discharge and water temperature under climate change, Global Environ. Change, 23, 450-464, doi:10.1016/j.gloenvcha.2012.11.002, 2013.
Van Vuuren, D. P., Edmonds, J., Kainuma, M., Riahi, K., Thomson, A., Hibbard, K., Hurtt, G. C., Kram, T., Krey, V., and Lamarque, J.-F. : The representative concentration pathways: an overview, Climatic Change, 109, 5-31, 2011.

Varis, O., Kummu, M., and Salmivaara, A.: Ten major rivers in monsoon Asia-Pacific: An assessment of vulnerability, Appl. Geogr., 32, 441-454, doi:10.1016/j.apgeog.2011.05.003, 2012.

Västilä, K., Kummu, M., Sangmanee, C. and Chinvanno, S.: Modelling climate change impacts on the flood pulse in the Lower Mekong floodplains, Water Clim. Change, 1, 67-86, 2010.

Veldkamp, T. I. E., Wada, Y., de Moel, H., Kummu, M., Eisner, S., Aerts, J. C. J. H., and Ward, P. J.: Changing mechanism of global water scarcity events: Impacts of socioeconomic changes and inter-annual hydro-climatic variability, Global Environ. Change, 32, 18-29, doi:10.1016/j.gloenvcha.2015.02.011, 2015.

Vogel, R. M. and Fennessey, N. M.: Flow duration curves. II. A review of applications in water resource planning, Water Resour Bull., 31, 1029-1039, 1995.

Vu, M. T., Raghavan, S. V., and Liong, S. Y.: SWAT use of gridded observations for simulating runoff - a Vietnam river basin study, Hydrol. Earth Syst. Sci., 16, 2801-2811, doi:10.5194/hess-162801-2012, 2012.

Wang, W., Lu, H., Yang, D., Sothea, K., Jiao, Y., Gao, B., Peng, X., and Pang, Z.: Modelling Hydrologic Processes in the Mekong River Basin Using a Distributed Model Driven by Satellite Precipitation and Rain Gauge Observations, PloS One, 11, e0152229, doi:10.1371/journal.pone.0152229, 2016.

Weedon, G. P., Gomes, S., Viterbo, P., Shuttleworth, W. J., Blyth, E., Österle, H., Adam, J. C., Bellouin, N., Boucher, O., and Best, M.: Creation of the WATCH Forcing Data and Its Use to Assess Global and Regional Reference Crop Evaporation over Land during the Twentieth Century, J. Hydrometeorol., 12, 823-848, doi:10.1175/2011jhm1369.1, 2011.

Yatagai, A., Kamiguchi, K., Arakawa, O., Hamada, A., Yasutomi, N., and Kitoh, A.: APHRODITE: Constructing a Long-Term Daily Gridded Precipitation Dataset for Asia Based on a Dense Network of Rain Gauges, B. Am. Meteorol. Soc., 93, 1401-1415, doi:10.1175/bams-d-11-00122.1, 2012. 